\title{
STUDI AGAMA \& ETIKA ISLAM DAN KEBERAGAMAAN MAHASISWA "Z" GENERATION: Kajian di Lingkungan Kampus ITB Bandung
}

\author{
Yedi Purwanto \\ Institut Teknologi Bandung \\ e-mail: yedipurwanto@gmail.com \\ Shohib Khoiri \\ Institut Teknologi Bandung \\ e-mail: shohibkhoiri2016@gmail.com
}

\begin{abstract}
Time is going on so fast, demanding man to have the quality and the courage to compete. Competition was sometimes make people forget the norm. To solve this problem it is required religion as a way of life. The method used herein are reviewing the literature and system of Islamic religious education activities in Bandung Institute of Technology (ITB). The findings of this study stated that the First, religious education in public universities is needed to foster the spirituality of younger generation. Second, "Z" generation is the object of da'wah who are very close to IT (information technology), so there must be a specific design of da'wa which is meetiing their need. Third, the role of Salman mosque is very central in implementing any Islamic $d a^{\prime} w a$ to the students of ITB.

Perkembangan zaman yang serba cepat, menuntut manusia untuk mempunyai kualitas dan berani bersaing. Persaingan itu kadang membuat manusia lupa akan norma. Untuk mengatasi persoalan tersebut maka diperlukanlah agama sebagai way of life. Metode yang digunakan tulisan ini adalah mengkaji literatur dan sistem kegiatan pendidikan agama Islam di lingkungan Institut Teknologi Bandung. Temuan penelitian ini menyatakan bahwa Pertama, pendidikan agama di perguruan tinggi umum sangat diperlukan guna memupuk spiritualitas generasi muda. Kedua, generasi "Z" merupakan objek dakwah yang sangat lekat dengan IT, oleh karena itu model dakwah yang memiliki kedekatan dengan IT merupakan sebuah keniscayaan. Ketiga, Peran Masjid Salman sangat sentral dalam mengejawantahkan berbagai dakwah islam kepada mahasiswa ITB.
\end{abstract}

Keywords: Islamic education; Salman Mosque; ITB; Bandung; "Z" generation 


\section{A. Pendahuluan}

Peran agama dalam kehidupan manusia diibaratkan seperti udara. Jika tanpa udara manusia akan mati raganya, maka tanpa agama manusia akan mati jiwanya. Baik raga maupun jiwa keduanya adalah dua unsur yang sangat penting pada diri manusia. Sebagaimana ditegaskan oleh Dawam Raharjo ${ }^{1}$ bahwa peran agama sangat penting dalam menopang raga yang kuat, jika keduanya kokoh maka manusia akan sampai pada posisi insan kamil. Insan kamil adalah kondisi manusia yang lengkap dan sempurna dalam posisi kemanusiaannya.

Perkembangan zaman yang sangat pesat membuat manusia dituntut untuk berlomba dan bersaing agar tak tertinggal, atau bahkan dapat berkembang, baik dalam hal ilmu pengetahuan, materi maupun pangkat dan jabatan. Di samping itu, ${ }^{2}$ perkembangan teknologi informasi yang semakin pesat membuat pergaulan mereka semakin luas dan semakin mudah untuk mengakses berbagai informasi. Jika hal ini tidak diimbangi dengan kekuatan agama yang kuat, maka akan berdampak pada hal-hal yang negatif. Dalam konteks ini pemahaman terhadap makna dan manfaat media yang dilandasi oleh pemahaman agama merupakan prasyarat bagi pembentukan insan kamil tersebut. ${ }^{3}$

Dampak negatif jauhnya masyarakat dari agama adalah munculnya berbagai macam permasalahan sosial. Hal tersebut sangat mungkin terjadi dikarenakan mereka mengalami kekosongan jiwa. Perilaku yang koruptif, pergaulan antara lelaki dan wanita tanpa batas, penyimpangan seksual, perdukunan dan hal-hal negatif lainnya merupakan dampak dari jauhnya masyarakat dari agama. Untuk mengatasi hal tersebut, maka pendidikan Islam di kampus, terlebih perguruan tinggi umum (PTU) memiliki peranan yang sangat penting. Hal ini karena mahasiswa yang merupakan objek didik di kampus adalah generasi yang akan berperan membangun negeri, youth today are the future leaders.

\footnotetext{
1987).

${ }^{1}$ Dawam Raharjo, Insan Kamil: Konsepsi Manusia Menurut Islam (Jakarta: Pustaka Grafitipers,

2Yoga S, Salam, "Dakwah di Internet: Konsep Ideal, Kondisi Objektif, dan Prospeknya”, Jurnal AlBayan Vol. 21, No. 31, 2015.

${ }^{3}$ Khomsiatul Mukarromah, "Membangun Insan Kamil dari Perspektif Media: Media Literasi sebagai Kontrol sosial” dalam Dirosat:Journal of Islamic Studies Vol. 1, No. 2, 2016; Yoga S, ibid.
} 
Institut Teknologi Bandung (ITB) yang merupakan salah satu PTU di Indonesia, di samping bermuara kepada pengembangan sains dan teknologi, juga memberikan pendidikan sosial yang diantaranya berbentuk pendidikan agama. Hal ini penting karena kebutuhan manusia pada umumnya tidak hanya mengembangkan kemampuan otak, tapi juga kehalusan jiwa.

Otak yang cerdas dengan jiwa yang hampa hanya akan menambah beban masalah bagi negeri, begitu pun sebaliknya. Pendidikan agama di ITB tidak bertujuan untuk menjadikan mahasiswa sebagai ulama yang tahu ilmu-ilmu agama hingga ke akarnya, akan tetapi bertujuan mencetak seorang teknokrat, birokrat atau ilmuan pada bidangnya masing-masing yang mengaplikasikan nilai-nilai agama. Sehingga saat mereka terjun di dunia kerja dengan profesinya masing-masing, mereka dapat menjaga nilai-nilai kesusilaan, terlebih dapat menjaga diri dari nilai-nilai yang dilarang menurut agama.

Tujuan dari penelitian ini adalah: pertama, untuk menelaah kedudukan pendidikan agama di dunia pendidikan Indonesia, kususnya perguruan tinggi. Kedua, mengkaji model pendidikan yang ideal khususnya bagi kalangan mahasiswa yang masuk kategori generasi "Z". Ketiga, mengkaji peran pendidikan agama Islam di lingkungan Institut Teknologi Bandung dalam mencetak generasi yang cerdas otak dan kokoh jiwa. Sedangkan metode penelitiannya dengan mengkaji litelatur-litelatur berkaitan dengan pendidikan, khususnya pendidikan generasi muda dan mengkaji system dan kegiatan pendidikan agama Islam di lingkungan Institut Teknologi Bandung.

\section{B. Pendidikan Islam untuk Mahasiswa ITB}

\section{Pendidikan Agama di Perguruan Tinggi Umum}

Kedudukan pendidikan agama di lingkungan perguruan tinggi umum (PTU) merupakan salah satu pembahasan yang ramai diperbincangkan oleh banyak pakar pendidikan. Memang UU No. 4 Tahun 1950 mengenai pendidikan agama di lingkungan PTU belum menjelaskan secara spesifik mengenai model pengajarannya. Hal ini dikerenakan banyaknya kepentingan-kepentingan dalam proses pembentukan UU tersebut, diantaranya adalah kepentingan politik dan sentimen keagamaan mengingat saat itu Partai Komunis Indonesia 
masih memiliki peranan yang kuat. Meski demikian, pendidikan agama di PTU tidak bisa dikesampingkan, karena peranannya sangat penting dalam membentuk sarjana-sarjana berkarakter baik yang ahli dalam bidangnya masingmasing. Terlebih Indonesia meskipun bukan negara agama, tapi ia adalah negara beragama, artinya memperhatikan hal-hal yang berkaitan dengan keagamaan. Hal ini sangat jelas pada sila pertama Pacasila, yaitu "Ketuhanan Yang Maha Esa", terlebih pada UUD 1945 Pasal 28E Ayat (1) dinyatakan: "Setiap orang bebas memeluk agama dan beribadat menurut agamanya."

Fenomena kemerosotan atau degradasi moral menjadi sesuatu yang sangat kita khawatirkan saat ini. Hampir setiap hari media meliput berita-berita buruk yang menggambarkan kemerosotan akhlak masyarakat, mulai dari perjudian, narkoba, pencurian, pemerkosaan, pembunuhan, perzinaan dan perilaku lainnya. Lebih mengkhawatirkan lagi ketika pelakunya adalah kalangan remaja yang pada umumnya usia mahasiswa. Bahkan sebagian dari perilaku buruk tersebut seakan menjadi sebuah tren yang jika tidak dilakukan dianggap ketinggalan zaman. Kasus pembunuhan terhadap dosen yang dilakukan oleh seorang mahasiswa di PTS Medan beberapa waktu lalu sangat menohok marwah pendidikan tinggi kita. Hal ini pun menujukan kemerosotan akhlak mahasiswa terhadap dosennya, dimana dosen tidak lagi menjadi sosok yang dihormati oleh mahasiswa. Lebih dari itu, maraknya penyebaran narkoba dan sikap korupsi yang semakin membudaya menunjukan bahwa pendidikan agama pada level perguruan tinggi masih menunjukkan kekuarangan. ${ }^{4}$

Melihat fakta di atas, sudah seharusnya kita sebagai praktisi pendidikan, khususnya di perguruan tinggi untuk berani mengevaluasi pendidikan agama bagi mahasiswa. Adakah sesuatu yang salah dalam pendidikan kita sehingga fenomena di atas dapat terjadi? Hubungan antara fakta krisis akhlak dengan pendidikan ini pantas untuk dikaji ulang mengingat akan posisi dan fungsi pendidikan yang sangat krusial dalam membina mental dan moral bangsa. Pentingnya pendidikan akhlak ini sesuai dengan pepatah Arab: "Sebuah bangsa akan bangkit jika akhlak pendidiknya baik, tetapi akan hancur jika akhlak pendidiknya hancur". ${ }^{5}$

\footnotetext{
${ }^{4}$ Abdurrahman Mas'ud, Islamic Education, Democracy and Civil Society (Semarang: Universitas Islam Negeri Walisongo Semarang. 2016), h. 7.

5Furqan, Pedagogi Spiritual (Bandung; Universitas Pendidikan Indonesia Bandung, 2016), h. 2.
} 
Tentunya pendidikan yang dimaksud tidak hanya proses transfer pengetahuan kepada peserta didik, akan tetapi pendidikan yang menjadi media dalam membangun kesadaran, kedewasaan dan kepribadian mereka yang kemudian populer dengan istilah pendidikan karakter. (Hal ini sesuai dengan pengertian pendidikan yang tertuang dalam Undang-Undang Sisdiknas No. 20 Tahun 2003 Bab I, bahwa pendidikan adalah pembentuk kepribadian bangsa, baik secara spiritual, moral maupun sosial).

Dalam Undang-Undang Sisdiknas Tahun 2003 Pasal 1 ayat (2) bahwa Pendidikan Nasional harus berdasarkan Pancasila dan Undang-undang Dasar Negara Republik Indonesia Tahun 1945 yang berakar pada nilai-nilai agama, kebudayaan nasional dan tanggap terhadap tuntutan perubahan zaman. Kegagalan pendidikan kita saat ini diantaranya karena dunia pendidikan kita selama ini hanya menitikberatkan pada kecerdasan intelektual dan kurang perhatin terhadap pembentukan karakter. Padahal dalam Islam, ilmu bukan sekedar untuk dikuasai dan menjadi wawasan bagi peserta didik, tetapi harus menjadi kesadaran dan amalan dalam kehidupannya. ${ }^{6}$

Kategori definitif pendidikan agama dengan tujuan menciptakan Insan Kamil diantaranya sebagai berikut: Pertama, pendidikan agama dipahami dan dikembangkan dari ajaran dan nilai-nilai fundamental yang terkandung dalam sumber ajaran dan nilai-nilai agama, yaitu kitab suci serta nilai kebaikan dan kebajikan dalam agama. Dalam pengertian ini, pendidikan agama dapat berupa teori dan pemikiran yang dikembangkan atau dibangun berlandaskan pada sumber-sumber dasar tersebut.

Kedua, pendidikan agama dimaksudkan sebagai upaya mendudukkan agama dan nilai-nilainya agar agama menjadi way of life seseorang. Dalam pengertian ini pendidikan agama dapat berwujud: 1) aktifitas yang dilakukan oleh seseorang atau lembaga untuk membantu peserta didik dalam menanamkan dan atau menumbuhkembangkan ajaran agama dan nilai-nilainya; 2) segenap fenomena atau peristiwa tertentu yang dampaknya ialah tertanamnya ajaran agama atau nilai-nilainya pada salah satu atau beberapa pihak.

Ketiga, Pendidikan agama dipahami sebagai proses dan praktik penyelenggaraan pendidikan yang selama ini berlangsung dan berkembang dalam sejarah

${ }^{6}$ Ibid., h. 4. 
umat di masing-masing agama. Pendidikan agama dalam pengertian ini dipahami sebagai proses pembudayaan dan pewarisan ajaran agama, budaya dan peradaban penganut agama bagi generasi ke generasi sepanjang sejarahnya. ${ }^{7}$

Dalam salah satu ayatnya Allah berfirman: "Allah akan meninggikan orangorang yang beriman dan yang diberi ilmu beberapa derajat". ${ }^{8}$ Ayat ini dengan jelas menerangkan bahwa kemulian seseorang tidak hanya bergantung pada banyaknya ilmu yang dimiliki, akan tetapi juga pada iman atau akhlak yang menjadi landasan hidupnya, oleh sebab itu ayat diatas diawali dengan "beriman" sebelum berilmu. Hal ini juga selaras dengan hadis Rasulullah: "Siapa yang Allah kehendaki kebaikan pada dirinya, maka Dia akan mencerdaskannya dalam beragama."9 Dari ayat dan hadis tersebut yang kemudian digabungkan dengan tujuan pendidikan sebagaimana termaktub dalam Undang-Undang Sisdiknas Tahun 2003 di atas, maka kita dapat mengambil kesimpulan bahwa generasi unggulan yang harus dibangun dalam sistem Pendidikan Nasional adalah generasi yang cerdas secara otak dan emosional, memiliki kekuatan spiritual keagamaan, pengendalian diri, kecerdasan, akhlak mulia serta keterampilan yang diperlukan dirinya, agama, bangsa dan negara. ${ }^{10}$

Berdasarkan teks al-Qur'an serta beberapa pendapat para ahli di atas dapat ditegaskan bahwa dalam kaitannya dengan ilmu pengetahuan dan teknologi, maka peran dari Pendidikan Agama adalah mengembangkan kemampuan peserta didik dalam memahami, menghayati, dan mengamalkan nilai-nilai agama yang menyerasikan penguasaanya dalam ilmu pengetahuan, teknologi dan seni. ${ }^{11}$ Ilmu pengatahuan dan teknologi yang diberikan sentuhan spiritualitas merupakan sesuatu yang niscaya. ${ }^{12}$

\footnotetext{
${ }^{7}$ Nurudin, Perbandingan Pengelolaan Pendidikan Agama Pada Sekolah di Indonesia dan Sekolah Republik Indonesia Tokyo (Jakarta: Pusat Penelitian dan Pengembangan Pendidikan Agama dan Keagamaan, Kementerian Agama Republik Indonesia.2015), h. 7-8.

${ }^{8}$ (QS. Al-Mujadilah: 11)

${ }^{9}$ HR. Bukhari, hadis no. 2948 dab Muslim, hadis no. 1037.

${ }^{10}$ Asep Fathurrazi, Strategi Peningkatan Mutu Pendidikan Islam (Tulungagung: Sekolah Tinggi Agama Islam Muhammadiyah Tulungagung, 2016).

${ }^{11}$ Rudi Ahmad Suryadi, Visi dan Paradigma Pendidikan Agama Islam (PAI): Kualitas, Integratif, dan Kompetitif(Cianjur: STIS Nahdhatul 'Ulama Cianjur 2016), h. 1.

${ }^{12}$ Hadi Masruri dan Imron Rossidy, "Filsafat Sains dalam Al-Qur'an: Melacak Kerangka Dasar Integrasi Ilmu dan Agama" dalam El-Qudwah (04), 2007.
} 
Keniscayaan penyatuan ilmu pengetahuan dan teknologi dengan agama didasarkan pada prinsip epistemologik bahwa pada dasarnya ilmu itu satu. Tidak ada pemilahan ilmu antara ilmu pengetahuan dan teknologi dengan agama. ${ }^{13}$ Penyatuan ilmu itulah yang akan mendatangkan kemanfaatan ilmu secara sempurna. Ilmu yang memiliki nilai spiritual akan mengarahkan pemakainya untuk menjalankan fungsi dirinya dalam memanfaatkan ilmu itu dengan sebaik-baiknya, untuk tujuan kebaikan umat manusia. ${ }^{14}$

\section{Problematika dan Pendidikan Agama Generasi " $\mathrm{Z}$ "}

Mahasiswa dalam hitungan usia masuk kategori generasi "Z", yaitu generasi yang lahir dalam rentang waktu antara tahun 1995-2010. Setiap generasi memiliki karakteristik dan problematikanya masing-masing, begitu juga dengan generasi "Z". Diantara karakteristiknya adalah sebagaimana yang dijelaskan oleh Hari Wibawanto adalah fasih dalam menggunakan perangkat teknologi, senang bersosial dengan berbagai kalangan khususya menggunakan media sosial, ekspresif cenderung toleran dengan perbedaan kultur dan sangat peduli dengan lingkungan, cepat berpindah dari satu pemikiran/pekerjaan ke pemikiran/pekerjaan yang lain. Khusus kaitannya dengan perangkat teknologi, mereka cenderung sering menggunakannya. Mereka menghabiskan waktu 7.5 jam perhari menggunakan gawai digital, 22\% dari mereka masuk ke akun media sosial lebih dari 10 kali sehari, 75\% dari mereka memiliki ponsel sendiri yang 25\% digunakan untuk media sosial, 54\% untuk teksting dan 24\% untuk instan messaging. ${ }^{15}$

Dalam proses belajar, Adang Surahman menjelaskan bahwa mereka memiliki beberapa karakteristik, diantaranya diawali dengan menyimak, berfikir dan berkonsentrasi, berinteraksi yang kemudian bermuara pada kondisi kontinu atau ada jeda dan cepat atau lambat. ${ }^{16}$ Karena mereka begitu akrab

\footnotetext{
${ }^{13}$ Ibid.

${ }^{14}$ Rudi Ahmad Suryadi, Visi dan Paradigma Pendidikan Agama Islam (PAI) ...

${ }^{15}$ Hari Wibawanto, "Generasi Z dan Pembelajaran di Pendidikan Tinggi," Simposium Nasional Pendidikan Tinggi, ITB, Bandung, Senin, 24 Oktober 2016, tersedia dalam laman http://event. elearning.itb.acid/assets/download/materi3.pdf, h. 4-5

${ }^{16}$ Adang Surahman, "Pengalaman sebagai Dosen ITB Menghadapi Mahasiswa Generasi Z", Simposium Nasional Pendidikan Tinggi, ITB, Bandung, Senin, 24 Oktober 2016, tersedia dalam laman http://eventelearning.itb.acid/assets/download/materi2.pdf - h. 1.
} 
dengan teknologi informasi, Hari Wibawanto menganjurkan agar memanfaatkan dawai teknologi dan media sosial dalam proses pembelajarannya. ${ }^{17}$

Dalam analisanya, Yanti Rubiyanti menjelaskan bahwa generasi "Z" memiliki mobilitas yang lebih tinggi daripada generasi sebelumnya. Dukungan teknologi membuat mereka semakin mudah untuk menjaungkau berbagai tempat di berbagai wilayah. Pertemuan dapat dilakukan dimana pun, baik di kampus, di kafe, mall dan sebagainya ${ }^{18}$ Dosen dapat memanfaatkan fenomena ini dengan menjadikan kecenderungan berkelompok sebagai sarana membangun kemampuan kerjasama, leadership dan norma berinteraksi.

Mereka juga lebih cenderung kuat belajar dengan cara visual. Oleh karena itu memberikan contoh yang bersifat visual akan lebih membekas daripada memberikan nasihat dengan verbal. Mengajar dengan cara visualisasi, turun ke lapangan, kegiatan pengamatan, dan observasi perlu dikuatkan daripada memberikan kuliah secara lisan. Lebih dari itu, karena mereka memiliki keakraban yang kuat dengan teknologi informasi, maka pendidikan sopan santun menjadi hal yang mutlak diajarkan pada mereka. ${ }^{19}$ Secara khusus yang perlu disampaikan kepada generasi muda ini adalah pendidikan tentang norma atau sopan santun dalam berinteraksi via media sosial. Landasan normatif yang mereka miliki akan membuat mereka memiliki kemampuan dalam memilih informasi, mampu mengendalikan diri, dan tidak mudah terpicu atau terprovokasi oleh informasi yang belum jelas, serta memliki keterbukaan dalam perbedaan.

Dapat dipahami bahwa generasi "Z" ini adalah generasi yang lahir dalam era teknologi informasi. Oleh karena itu mindset dari generasi ini adalah mindset teknologis dan cenderung positifistik, sehingga mereka lebih mudah mempercayai realitas dengan ukuran-ukuran objektif, empirik, dan rasional. Dengan kondisi objektif semacam itu maka pendidikan terhadap generasi

\footnotetext{
${ }^{17}$ Ibid., h. 13.

18Yanti Rubiyanti, "Perilaku Generasi Z dengan Karakteristiknya serta Pengaruhnya terhadap Cara Belajar dari Sisi Psikologi dan Pendidikan”, Simposium Nasional Pendidikan Tinggi, ITB, Bandung, Senin, 24 Oktober 2016, tersedia dalam laman http://event.elearning.itb.ac.id/assets/download/ materi5.pdf-h. 20.

${ }^{19}$ Khomsiatul Mukarromah, "Membangun Insan Kamil dari Perspektif Media: Media Literasi sebagai Kontrol sosial” dalam Dirosat:Journal of Islamic Studies, Vol. 1, No. 2, 2016.
} 
mudah sebaiknya mengikuti kondisi objektif itu. ${ }^{20}$ Pemahaman terhadap kondisi objektif remaja akan memungkinkan mereka merasa memperoleh perhatian dari orang tua maupun pendidik di perguruan tinggi. Perasaan diperhatikan akan memunculkan perasaan diterima sehingga secara psikologis mereka mudah untuk menerima ajaran yang disampaikan.

\section{Pendidikan Agama dan Etika Islam di ITB}

Institut Teknologi Bandung merupakan salah satu Perguruan Tinggi Negeri (PTN) di Indonesia. Dalam statusnya Perguruan Tinggi Umum (PTU), sebagaimana UU No 4. Tahun 1950, ITB berkewajiban memberikan pendidikan agama kepada peserta didiknya sesuai dengan silabus yang ditentukan. Dalam target pencapaiannya, pendidikan agama di ITB tidak mentargetkan para mahasiswa menjadi seorang faqih atau alim dalam agama. Hal ini karena studi utama mereka bukan studi agama, melainkan ilmu pengetahuan dan teknologi. Oleh sebab itu, target utama pendidikan mereka adalah menjadikan sarjana-sarjana yang handal dalam bidang sains dan teknologi yang berkarakter agama. Dengan harapan setelah mereka lulus dan mendapat gelar sarjana, maka mereka akan terjun ke tengah masyarakat sebagai akademisi, birokrat, teknokrat, politisi atau pengusaha yang berkarakter baik dan mengaplikasikan nilainilai Islam.

Untuk mencapai cita-cita tersebut bukanlah hal yang mudah, karena membutuhkan kerjasama tenaga pendidik dan membutuhkan waktu yang tidak sebentar. Oleh sebab itu, dalam silabusnya, bahan mata kuliah pendidikan agama dan etika Islam ITB lebih cenderung pada pembentukan etika Islam dengan tambahan teori-teori dasar ilmu agama Islam. Berikut adalah silabus Pendidikan Agama dan Etika Islam ITB:

\section{Kurikulum ITB 2013-2018 - Program Sarjana}

Pendidikan Agama dan Etika di ITB mengacu pada Outcome Based ABET Amerika Serikat, yaitu pada poin " $F$ ", “H”, dan "J”. Ketiga poin tersebut adalah: a)

\footnotetext{
20Darmiyati Zuchdi, "Pendekatan Pendidikan Nilai Secara Komprehensif sebagai Suatu Alternatif Pembentukan Akhlak Bangsa”, Cakrawala Pendidikan:Jurnal Pendidikan, 2, 2001.
} 
An understanding of professional and ethical responsibility; b) The broad education necessary to understand the impact of engineering and physics solutions in a global, economic, environmental, and societal; c) A knowledge of contemporary issues.

Silabus yang digunakan saat ini dengan tujuan melahirkan sarjana sesuai poin di atas adalah: a) Menguasai tentang konsep aqidah Islam; b) Kedudukan, tugas, dan tujuan hidup manusia; c) Islam holistik; d) Relasi sains, teknologi, dan agama; e) Sumber Hukum Islam; f) Etika kepada Allah, manusia, dan lingkungan; g) Etika saintis; h) Etika profesi; i) Masyarakat madani; j) Ekonomi dan perbankan syariah; k) Etika berpolitik dalam Islam

Bobot perkuliahan Pendidikan Agama dan Etika di ITB sebesar 2 SKS (2 jam), mahasiswa dapat mengambilnya pada semester III atau IV. Selain di kelas, mahasiswa pun diwajibkan mengikuti spiritual camp (SC) selama dua hari satu malam. Pelaksanaan kegiatan ini dilaksanakan berkerjasama dengan Masjid Salman ITB. Dalam kegiatan tersebut mahasiswa memperoleh tambahan materi tentang keIslaman ditambah dengan latihan aplikasi ibadah maḥdah. Disamping itu, mahasiswa juga diwajibkan mengikuti mentoring yang diselenggarakan dan dibimbing oleh para asisten agama. Hal ini penting untuk mengetahui sejauh mana kemampuan membaca al-Qur'an, shalat dan amaliah ibadah lainnya.

\section{Masjid Salman ITB dan Tantangan Global}

Masjid Salman ITB berkontribusi besar dalam mengembangan pendidikan agama Islam mahasiswa ITB. Salman merupakan laboratorium Pendidikan Agama dan Etika, dan pusat dakwah Islamiah di ITB. Dalam menghadapi problematika sosial di masyarakat kampus dan sekitarnya, maka dosen-dosen Agama dan Etika ITB bekerjasama dengan pihak yayasan Masjid Salman ITB melakukan berbagai kegiatan da'wah islāmiyyah. Kegiatan keislaman Salman dimotori oleh organisasi-oraganisasi yang dijalankan sebagaian besar oleh mahasiswa ITB, diantaranya adalah GAMAIS - ITB (Gabungan Mahasiswa Islam ITB), MATA - ITB (Majelis Ta'lim ITB), Kharisma - ITB, PAS, Aksara, Pustena dan lain-lain. Organisasi-organisasi tersabut merupakan wadah kaderisasi keislaman yang khususnya diperuntukkan bagi mahasiswa ITB. Selain itu ter- 
dapat pula Pusat Kajian Halal dan Pusat Kajian Wakaf, Rumah Amal Salman dan Rumah Sakit Salman yang saat ini sedang dalam proses pembangunan. ${ }^{21}$

Dalam tulisan ini hanya akan menyoroti satu kegiatan yang banyak diminati mahasiswa ITB. Kegiatan itu adalah Sekolah Pra Nikah, atau Pendidikan Pra Nikah. Kegiatan ini banyak diminati mahasiswa terutama karena pertimbangan bahwa materi yang disampaikan sangat penting bagi mereka untuk mempersiapkan kehidupan mereka kelak ketika mereka berkeluarga. Sekolah pra-nikah juga memberi mereka pengetahuan mengenai free-sex dan serta seks sesama jenis yang orientasi akhirnya adalah agar mereka mampu menghindarkan diri dari dan menolak pola hidup semacam itu.

Arti penting kegiatan Sekolah Pra Nikah dapat dikaitkan dengan hegemoni budaya barat yang bertentangan dengan budaya ketimuran dan ajaran agama. ${ }^{22}$ Hegemoni Barat masuk ke dalam ranah kehidupan melalui berbagai jejaring teknologi informasi dalam berbagai bentuknya. Yang menjadikan keprihatinan di kalangan masyarakat secara umum terhadap realitas dominasi budaya Barat tersebut adalah terkait dengan model kehidupan Barat yang bertentangan dengan budaya Timur, yang jika budaya itu tidak disampaikan secara tepat akan menimbulkan permasalahan dalam kehidupan berkeluarga dan bermasyarakat. ${ }^{23}$ Untuk memperoleh gambaran mengenai spiritualitas mahasiswa ITB berikut hasil wawancara yang dilakukan. ${ }^{24}$

Terkait dengan pertanyaan mengenai lama kuliah di ITB, Gambar 1 menunjukkan proporsi bahwa jumlah terbesar dari responden adalah mahasiswa yang telah menjalani kuliah di ITB lebih dari tiga tahun. Proporsi seperti itu mengandung asumsi bahwa mahasiswa yang telah menjalani masa kuliah di ITB lebih dari tiga tahun lebih mengenal program di kampus, termasuk Program Sekolah Pra-Nikah.

\footnotetext{
${ }^{21}$ Anik Farida, "Islamisasi Sains dan Saintifikasi Islam: Model Manajemen Pemberdayaan di Masjid Salman ITB Bandung” dalam Harmoni: Jurnal Multikultural dan Multireligius, Vol. 13, No. 1, 2014.

22Ibid.

${ }^{23}$ Noor Azizah, Aulia Hening, Uswatun Hasanah, "Pengaruh Perkembangan IT terhadap Intensitas Ibadah Mahasiswa S1 STEI ITB," laporan penelitian, 2016,

${ }^{24}$ Wawancara dilakukan oleh Frideyas, Ristiya, dan Denobea (mahasiswa semester III ITB); pada tahun 2015.
} 


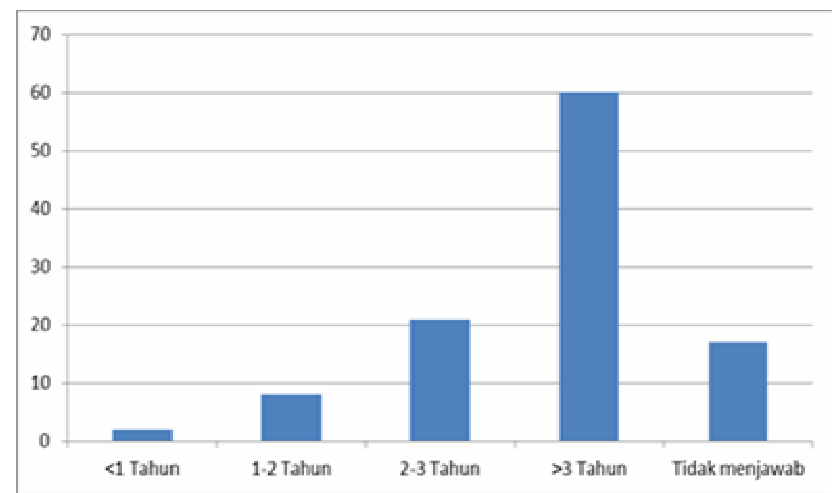

Gambar 1.

Grafik Variasi Angkatan Responden

Dari hasil wawancara dengan para responden, didapatkan hasil bahwa mayoritas dari mereka telah mengetahui tentang Pendidikan Pra-Nikah. Hal ini dapat dipahami karena program Pendidikan Pra-Nikah merupakan program yang populer di kalangan mahasiswa ITB. Diseminasi program yang ada di Masjid Salman telah berjalan secara sistematis melalui beberapa media, baik media cetak maupun media elektronik. ${ }^{25}$

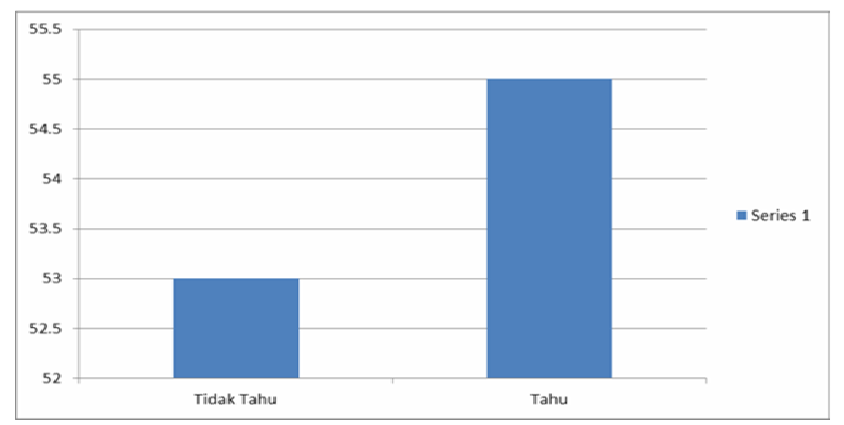

Gambar 2.

Grafik Pengetahuan Reponden Mengenai

“Apa Itu Pendidikan Pra Nikah?"

${ }^{25}$ Anik Farida, “Islamisasi Sains dan Saintifikasi Islam: Model Manajemen Pemberdayaan di Masjid Salman ITB". 
Berkait dengan pengetahuan responden mengenai Pendidikan Pra-Nikah, ada tiga jawaban tertinggi sebagaimana tampak dalam Gambar 3. Sebagaimana tampak dalam Gambar 3, pada umumnya memahami bahwa Pendidikan PraNikah mempelajari pernikahan menurut agama. Kelompok berikutnya memahami bahwa Pendidikan Pra-Nikah adalah program untuk mempersiapkan peran menjadi suami atau istri idaman; sementara kelompok ketiga memahami bahwa Pendidikan Pra-Nikah adalah program yang memberikan pemahaman mengenai hukum-hukum dalam ikatan suami istri. Perbedaan pernyataan ketiga kelompok ini menunjukkan perbedaan fokus perhatian dalam ranah kajian materi itu. Ini dapat dipahami karena level usia dan lama waktu menjadi mahasiswa berbeda sehingga fokus perhatian dan simpulannya.

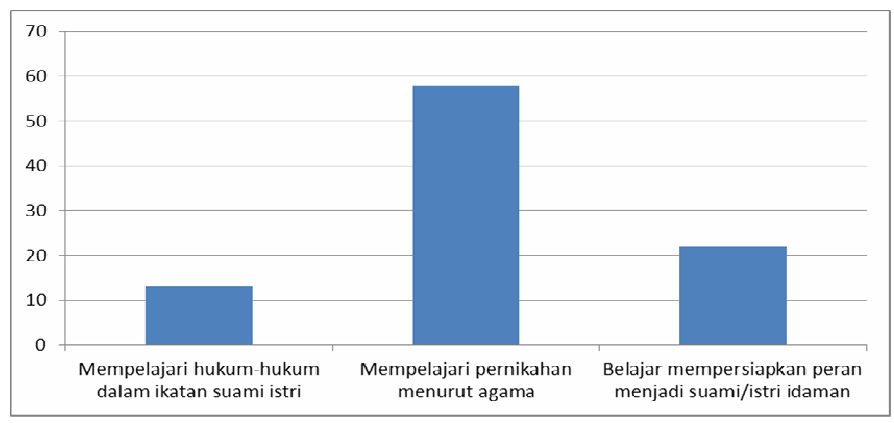

Gambar 3.

Grafik Pendapat Responden Mengenai

“Apa Itu Pendidikan Pra Nikah?"

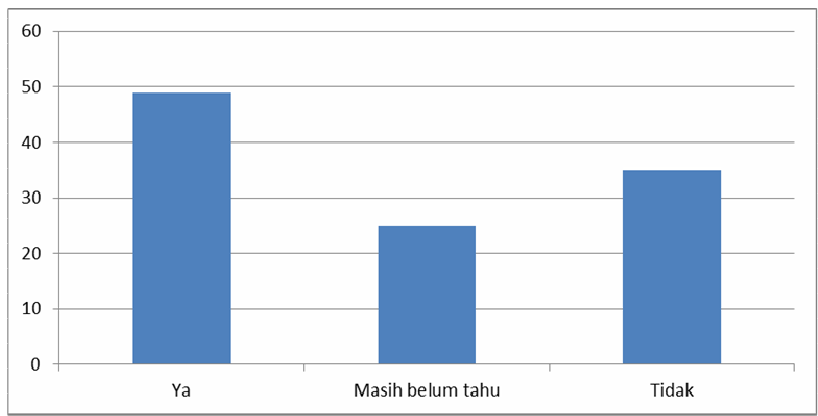

Gambar 4.

Grafik Rencana Responden Menikah

Walisongo, Volume 24, Nomor 2, November 2016 
Dalam kaitan antara Pendidikan Pra-Nikah dengan keinginan responden untuk segera menikah, ternyata, sebagaimana tampak dalam Gambar 4, sebagian besar menyatakan bahwa mereka ingin segera menikah, sebagian menyatakan tidak ingin segera menikah, dan sebagian yang lain menyatakan tidak tahu. Keinginan sebagian besar untuk segera menikah dimungkinkan oleh proses dan materi pendidikan yang menarik, sehingga membuat responden sebagian besar merasa ingin untuk segera menikah.

Berkait dengan arti penting Pendidikan Pra-Nikah itu, sebagian besar responden memandang pendidikan pra nikah merupakan program yang perlu dilaksanakan. Jawaban yang diperoleh dalam wawancara bahwa Pendidikan PraNikah merupakan program yang mereka perlukan dapat dirujuk melalui beberapa referensi. Sebagaimana dinyatakan oleh Fadhilatussaniah ${ }^{26}$ diseminasi program masjid yang diupayakan secara maksimal, baik dalam konten program, metode program dan pemberi materi, serta fasilitasnya membuat image-building yang positif bagi masjid Salman. Metode citizen journalism yang diterapkan oleh Masjid Salman benar-benar efektif dalam mendiseminasikan informasi mengenai program yang dijalankan oleh masjid tersebut.

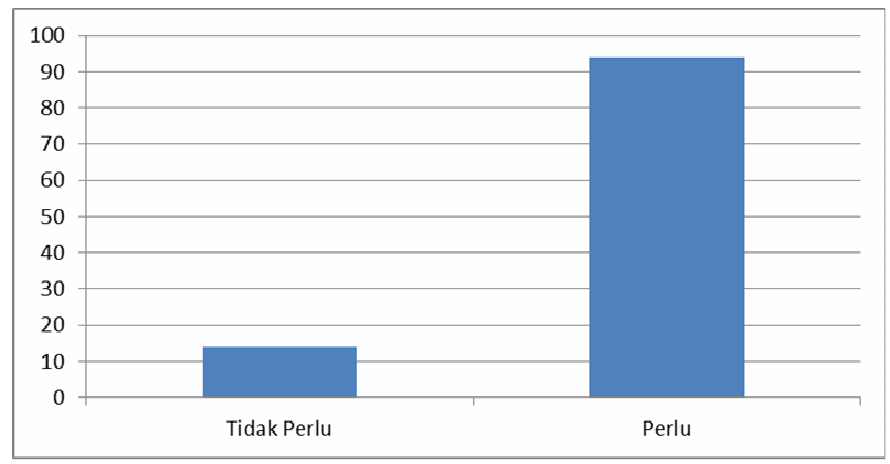

Gambar 5.

Grafik Perlu Tidaknya Pendidikan Pra Nikah bagi Responden

\footnotetext{
${ }^{26}$ Siti Fadhilatussaniah, "Metode Penyiaran Islam Yayasan Salman ITB dalam Menyajikan Informasi melalui Website: Studi Deskriptif tentang Website www.salmanitb.com', Tesis Diploma (Bandung: UIN Sunan Gunung Djati Bandung, 2011).
} 
Berdasarkan pelaksanaan program Pendidikan Pra-Nikah yang dilaksanakan pada tahun 2016 dapat diperoleh figur peserta yang mengikuti pendidikan tersebut. Data berikut, yang diperoleh dari wawancara telah mampu mengungkap kepesertaan program berdasar jenis kelamin, serta kelompok asal peserta.

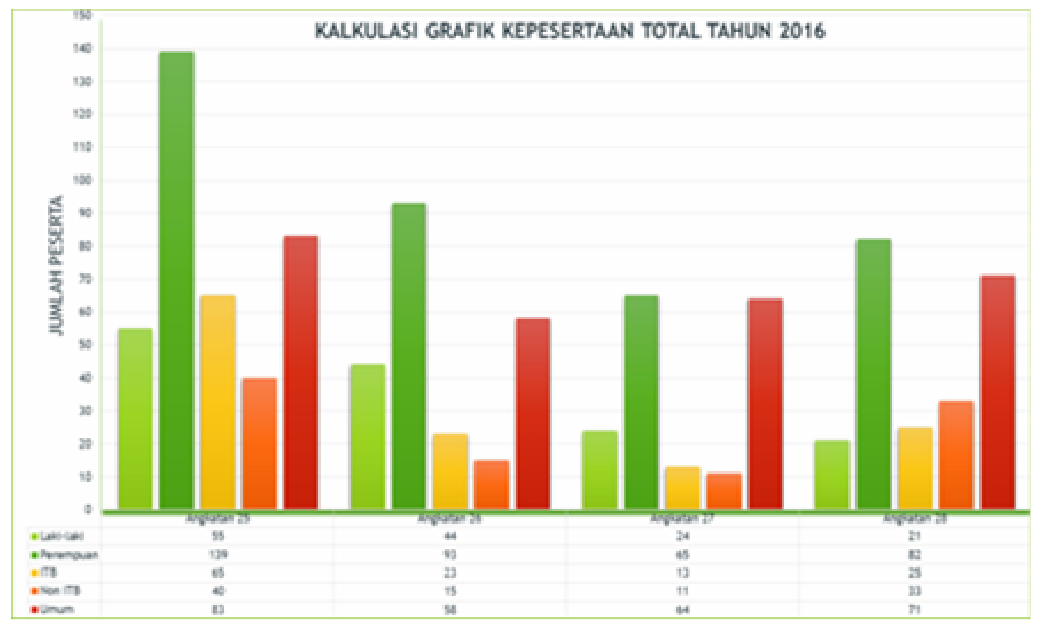

Gambar 6.

Grafik Kepesertaan Pendidikan Pra-Nikah

Grafik 6 di atas menunjukkan proporsi kepesertaan Pendidikan Pra-Nikah yang dilaksanakan oleh Masjid Salman ITB dalam angkatan ke 25, 26, 27, dan 28. Dari gambar tabel di atas bahwa kepesertaan Pendidikan Pra-Nikah meliputi pembeda berdasar jenis kelamin, yaitu laki-laki dan perempuan, asal institusi pendidikan, yaitu ITB dan non-ITB, serta peserta umum.

Dari data di atas tampak bahwa dalam setiap angkatan pendidikan, jika dilihat dari jenis kelamin maka perempuan menduduki proporsi yang lebih tinggi dibandingkan dengan peserta laki-laki, sementara peserta yang berbasis kelompok, yang proporsinya paling tinggi adalah yang dari kelompok umum. Proporsi dari kelompok umum menjadi sangat tinggi karena sebarannya luas, dalam makna cakupan wilayahnya, sementara kelompok kampus, baik ITB maupun non-ITB lebih kecil komparatif karena lingkupnya adalah mahasiswa, yang bagaimana pun dalam struktur kependudukan merupakan kelompok kecil. 
Gambar 7 menunjukkan secara spesifik kepesertaan laki-laki dalam tiap angkatan, dan Gambar 8 menunjukkan secara spesifik kepesertaan perempuan dalam tiap angkatan. Tampak dari Gambar 7 bahwa dalam empat kali pelaksanaan jumlah peserta laki-laki terbanyak terdapat dalam angkatan ke 25 dan angka kepesertaan yang kecil terdapat dalam angkatan ke 28.

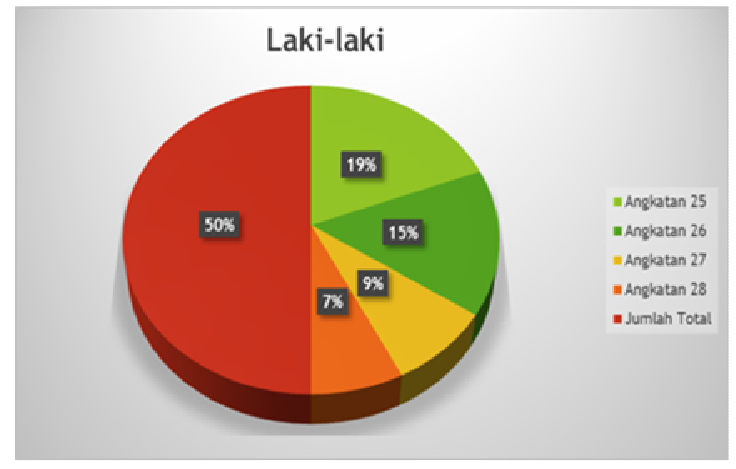

Gambar 7.

Kepesertaan Laki-laki dalam

Pendidikan Pra-Nikah per Angkatan

Sementara itu untuk kepesertaan perempuan, dari empat kali pelaksanaan, peserta perempuan yang paling besar terdapat dalam pelaksanaan Pendidikan Pra-Nikah angkatan ke-25 dan jumlah terkecil di angkatan ke-27.

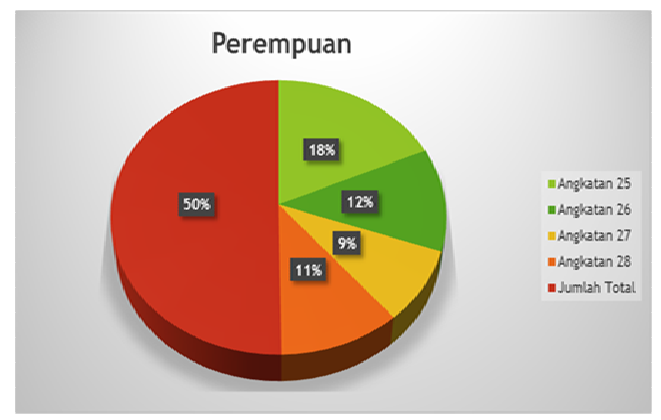

Gambar 8.

Kepesertaan Perempuan dalam Pendidikan Pra-Nikah per Angkatan 
Kepesertaan didasarkan asal kampus, sebagaimana tampak dalam Gambar 9 menunjukkan bahwa peserta dari ITB terbesar dalam pelaksanaan Pendidikan Pra-Nikah angkatan ke-25, dan yang paling kecil terdapat dalam angkatan ke27. Sementara dari Gambar 10 didapatkan data bahwa peserta non-ITB yang paling besar terdapat dalam Pendidikan Pra-Nikah angkatan ke-25 dan paling kecil terdapat dalam angkatan ke-27. Tingkat kepesertaan dalam Pendidikan Pra-Nikah di kalangan mahasiswa, baik mahasiswa ITB maupun non-ITB sangat ditentukan oleh waktu pelaksanaan pendidikan dibandingkan dengan jadwal dan agenda perkuliahan, sementara tingkat kepesertaan di kalangan umum ditentukan oleh kesibukan masing-masing personal.

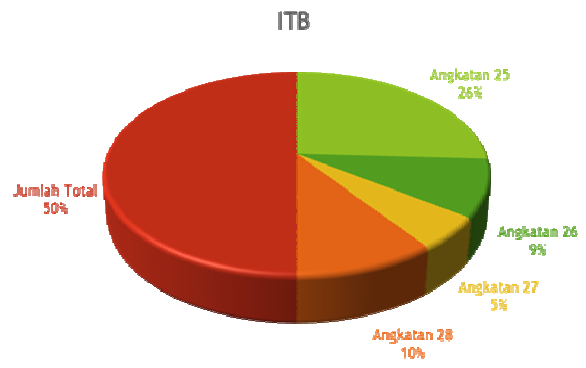

Gambar 9.

Kepesertaan Mahasiswa ITB dalam

Pendidikan Pra-Nikah per Angkatan

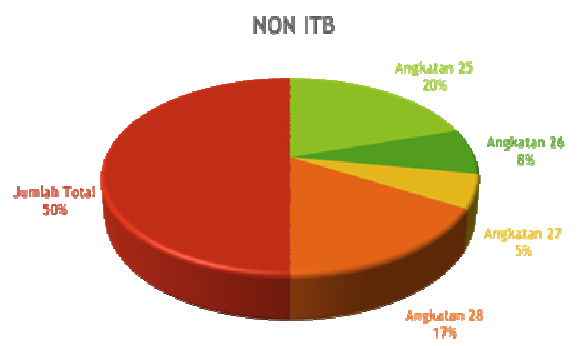

Gambar 10.

Kepesertaan Mahasiswa Non-ITB dalam Pendidikan Pra-Nikah per Angkatan

Walisongo, Volume 24, Nomor 2, November 2016 


\section{Amaliah Spritual Mahasiswa ITB}

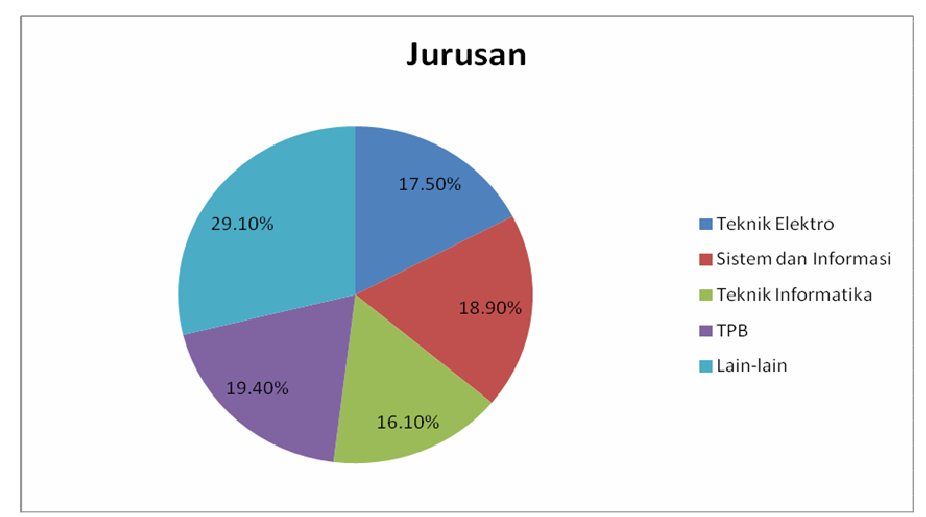

Gambar 11.

Asal Angkatan Responden

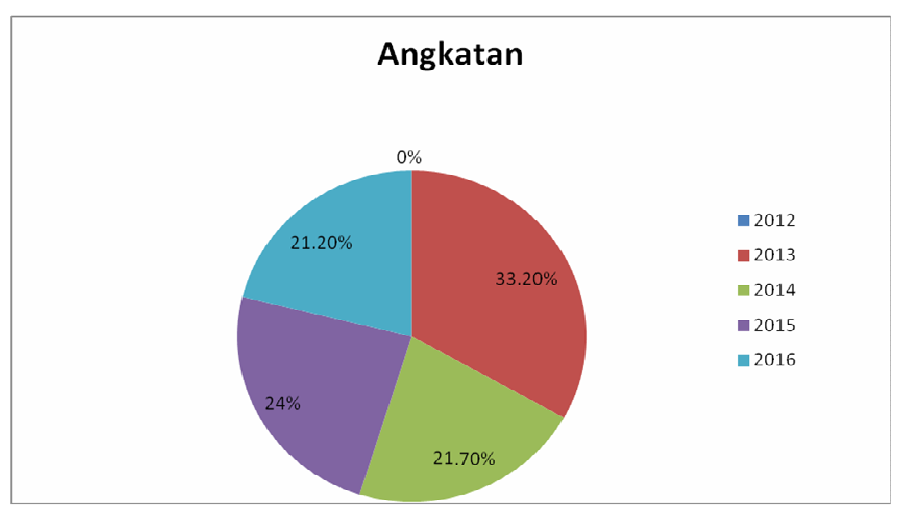

Gambar 12.

Responden Berdasar Jenis Kelamin

Beberapa item spiritualitas yang dicoba untuk diteliti dalam kajian ini adalah berkait rukun Islam. Asumsi dasar ditetapkannya item-item ini adalah bahwa setidaknya mahasiswa muslim telah mengorientasikan kehidupannya dengan panduan rukun Islam itu. Oleh karena itu item-item yang diteliti adalah yang berkait dengan shalat lima waktu dan shalat sunnah, membaca al-Qur'an, berpuasa, dan berinfaq. 
Data diperoleh dari mahasiswa ITB dari Sekolah Teknik Elektro dan Informatika (STEI) dari enam jurusan dan mahasiswa TPB. Total keseluruhan responden adalah sejumlah 217 mahasiswa. ${ }^{27}$

\section{Shalat Lima Waktu dan Shalat Sunnah}

Berkait dengan amaliah shalat, data yang didapatkan dalam penelitian ini adalah sebagaimana tampak dalam Gambar 13 menunjukkan bahwa mayoritas mahasiswa ITB menjalankan shalat fardhu secara penuh (61,30\%); 28,60\% mahasiswa pernah meninggalkan shalat kurang dari 5 kali; 7,40\% mahasiswa pernah meninggalkan shalat antara 5 sampai 10 kali; 1,40\% mahasiswa pernah meninggalkan shalat sebanyak 10 sampai 20 kali; dan 1,40\% mahasiswa pernah meninggalkan shalat lebih dari 20 kali dalam satu minggu.

Adapun mengenai shalat sunnah yang dilakukan oleh mahasiswa, Gambar 16 menunjukkan bahwa mahasiswa pada umumnya melakukan shalat sunnah rowatib, diikuti dengan shalat dhuha, shalat tahajud, dan lain-lain

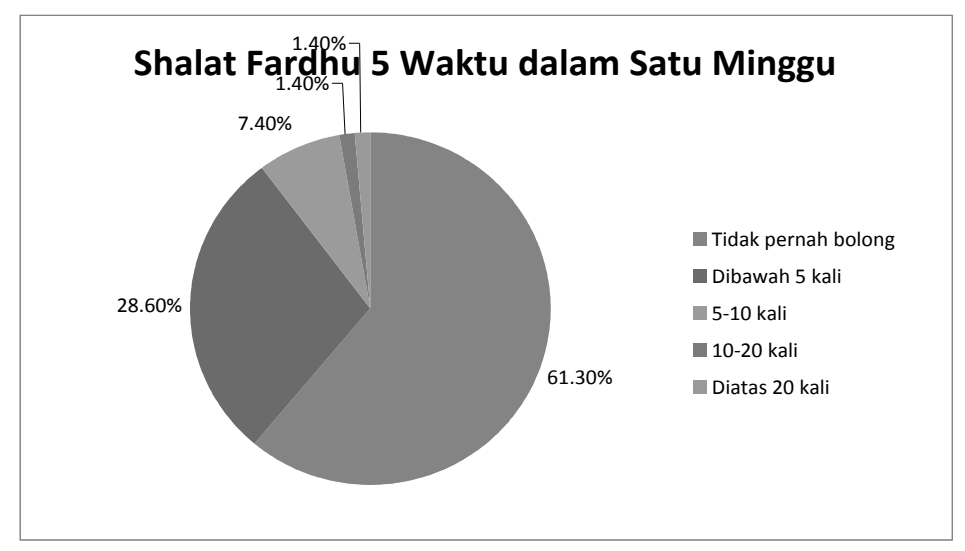

Gambar 13.

Amaliah Shalat Fardhu

\footnotetext{
${ }^{27}$ Data diperoleh dengan cara menyebarkan kuesioner; penyebaran kuesioner dilakukan oleh mahasiswa ITB semester III Sekolah Teknik Elektro dan Informatika (STEI), yaitu Noor Azizah Rahmafani, Aulia Hening Darmasti dan Uswatun Hasanah, , "Pengaruh Perkembangan IT terhadap Intensitas Ibadah Mahasiswa S1 STEI ITB."
} 


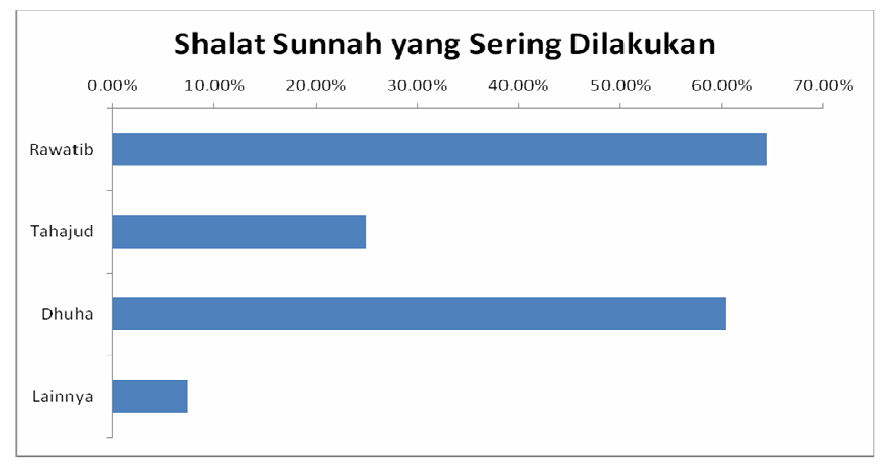

Gambar 14.

Amaliah Shalat Sunnah

\section{Membaca al-Qur'an}

Data mengenai aktivitas membaca al-Qur'an para mahasiswa tampak dalam Gambar 15 Mahasiswa ITB juga merasakan betapa pentingnya membaca Al-Quran dalam mengisi waktu mereka di tengah-tengah kesibukan yang menyita waktu mereka, mengikuti kuliah dan praktikum serta melaksanakan tugas-tugas kuliah lainnya. Ini adalah gambaran hasil riset terhadap kegiatan membaca al-quran di kalangan mahasiswa ITB.

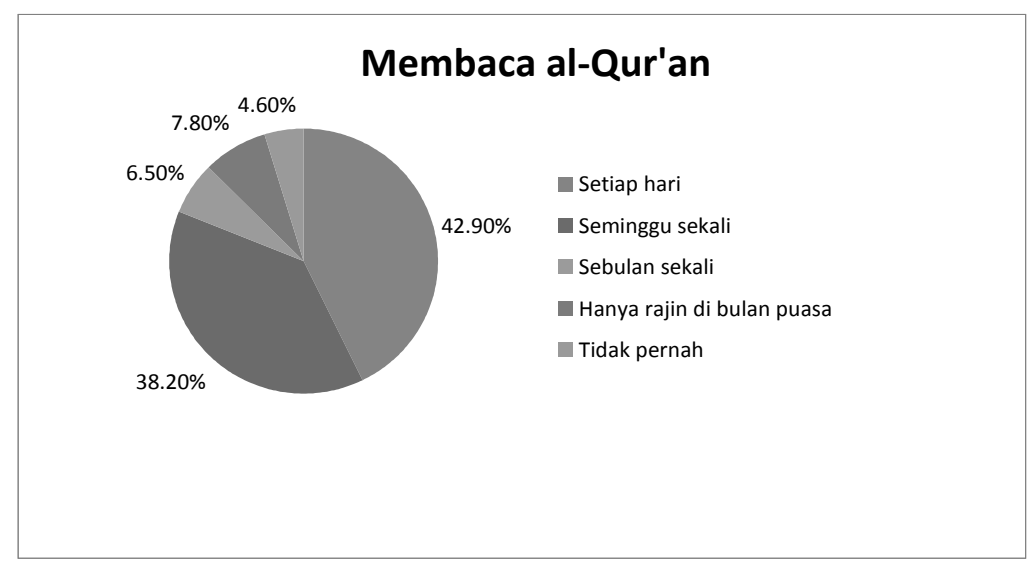

Gambar 15.

Amaliah Membaca Qur'an 


\section{Puasa yang Sering Dilakukan}

Puasa juga merupakan amaliah relijius yang banyak dilakukan oleh mahasiswa ITB. Dari beberapa jenis ibadah puasa, yang dilakukan oleh mayoritas mahasiswa adalah puasa Ramadhan. Lebih dari 80 persen mahasiswa menyatakan hal itu. Ini dapat dipahami karena puasa Ramadhan merupakan ibadah wajib bagi seorang muslim. Perintah untuk menjalankan ibadah puasa termuat di dalam al-Qur'an Surat al-Baqarah ayat 183. Puasa sunnah yang dilakukan oleh mahasiswa ITB adalah Senin-Kamis 5\%, tengah bulan (yaumul bid) $5 \%$, dan lain-lain $4 \%$.

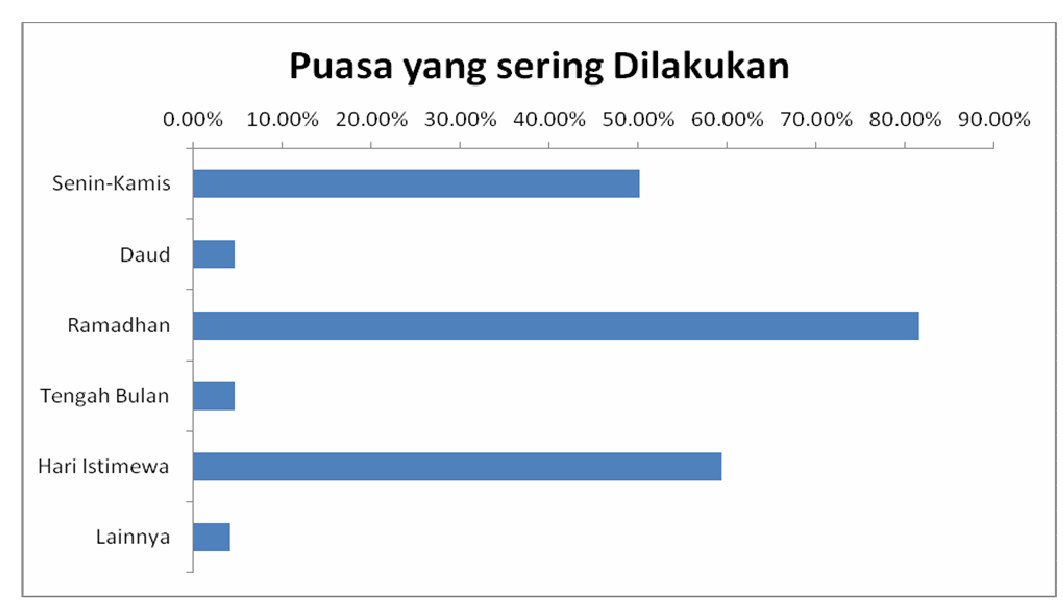

Gambar 16.

Grafik Amaliah Puasa

\section{Semangat Berinfaq}

Dalam hal berinfaq, dengan pengukuran melalui frekuwensi berinfaq dikalangan mahasiswa ITB, ditemukan data sebagaimana tampak dalam Gambar 19. Dari gambar tersebut tampak bahwa mayoritas responden menjawab bahwa mereka memberikan infaq dalam frekuwensi seminggu sekali (64,1\%), sebulan sekali $(18,40 \%)$, setiap hari $(6,90 \%)$, setahun sekali selama bulan Ramadhan (6\%), dan tidak pernah berinfaq (4,60\%).

Walisongo, Volume 24, Nomor 2, November 2016 


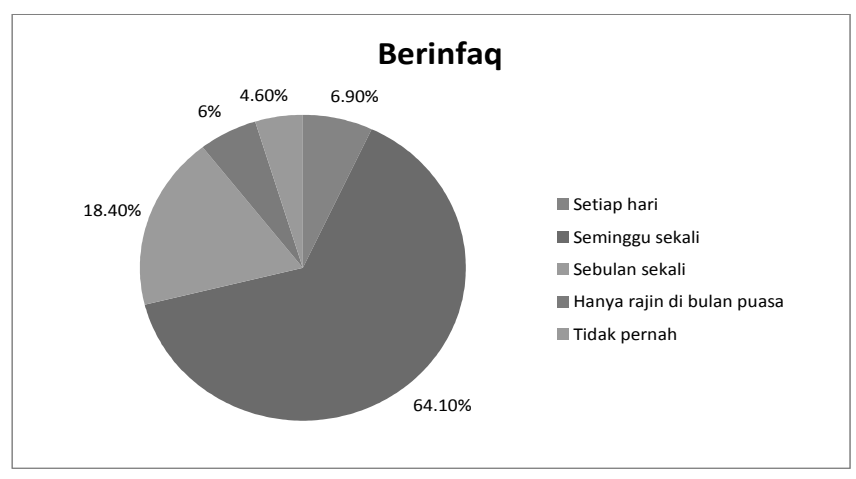

Gambar 17.

Amaliah Berinfaq

Pengamatan mengenai spiritualitas mahasiswa ITB dengan menggunakan gambar-gambar di atas belum dapat memberikan gambaran utuh mengenai spiritualitas mahasiswa muslim ITB secara menyeluruh, akan tetapi setidaknya data di atas dapat menjadi gambaran bahwa mahasiswa muslim ITB memiliki pengamalan keagamaan yang baik, sehingga dapat diasumsikan bahwa mereka juga memiliki kualitas spiritual yang baik

\section{E. Kontribusi IT Terhadap Perkembangan Spiritual Mahasiswa}

Berkait dengan kontribusi IT dalam perkembangan spiritual mahasiswa data di bawah ini dapat menjelaskan tentang kontribusi IT terhadap perkembangan spiritual mahasiswa Islam di ITB. Hasil riset ini dapat memberi informasi awal mengenai kegiatan dakwah islamiyah bagi perkembangan spiritual mahasiswa muslim di ITB. Grafik di bawah ini ingin menginformasikan tentang beberapa media yang digunakan mahasiswa ITB dalam mengisi ruhani mereka di kehidupan kampus mereka. Kemudian penggunaan gadget atau smart phone, serta kontribusi IT dalam kaitannya dengan kuantitas dan kualitas ibadah mahasiswa ITB.

\section{Media untuk Mendengarkan Ceramah/Kajian Islam}

Untuk mendapatkan informasi mengenai keIslaman mahasiswa ITB menggunakan berbagai media, dan lima media yang disebutkan oleh mahasiswa 
berdasarkan urutannya adalah bahwa mahasiswa sebagian besar memilih masjid sebagai tempat mencari ilmu keIslaman. Pilihan berikutnya adalah Youtube, dan diikuti dengan pengajian, TV, dan lainnya. Masjid 111 responden (51,2\%), TV 22 responden (10,1\%), Youtube 87 responden (40,1\%), Pengajian 48 responden $(22,1 \%)$, lainnya 17 responden $(7,8 \%)$.

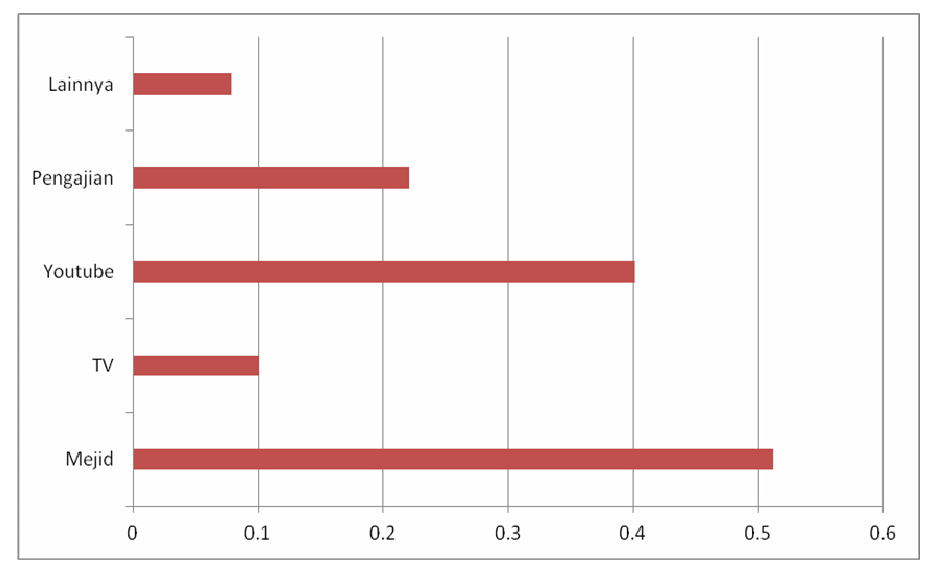

Gambar 18.

Sumber Kajian

Berdasarkan data di atas, dan sebagaimana secara visual dapat dilihat dalam Gambar 18 dapat dinyatakan bahwa masjid dan pengajian masih menjadi pilihan utama para mahasiswa ITB untuk memperoleh sumber keIslaman. Media online berupa Youtube juga menjadi pilihan yang banyak diminati mahasiswa selain media elektronik berupa siaran televisi, dan media lainnya.

\section{Penggunaan Gadget Secara Umum}

Untuk penggunaan gadget, mahasiswa ITB secara umum memanfaatkannya untuk berbagai tujuan. Data berikut menunjukkan peruntukan gadget oleh mahasiswa di ITB: Belajar 199 responden (91.7\%), Main game 93 responden (42,9\%), Nonton Film 121 responden (55,8\%), Medsos 193 responden (88,9\%), Ibadah 75 responden (34,6\%), lainnya 10 responden $(4,6 \%)$. 


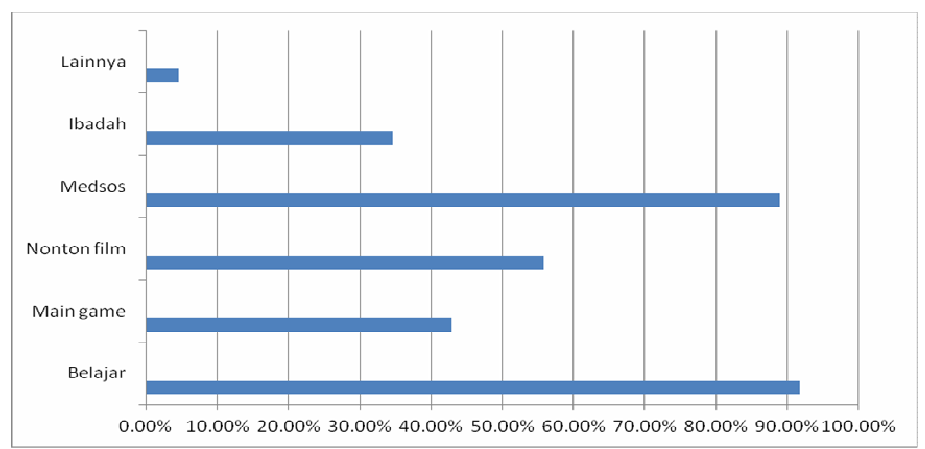

Gambar 19.

Penggunaan Gadget

Dari data yang didapat dapat diambil kesimpulan bahwa mayoritas mahasiswa memanfaatkan gadget sebagai media belajar selain sebagai hiburan (entertain) dan ibadah. Aktifitas hiburan dapat dirinci ke dalam beberapa aktifitas, yaitu media sosial, nonton film, dan main game

\section{Pengaruh IT terhadap Ibadah}

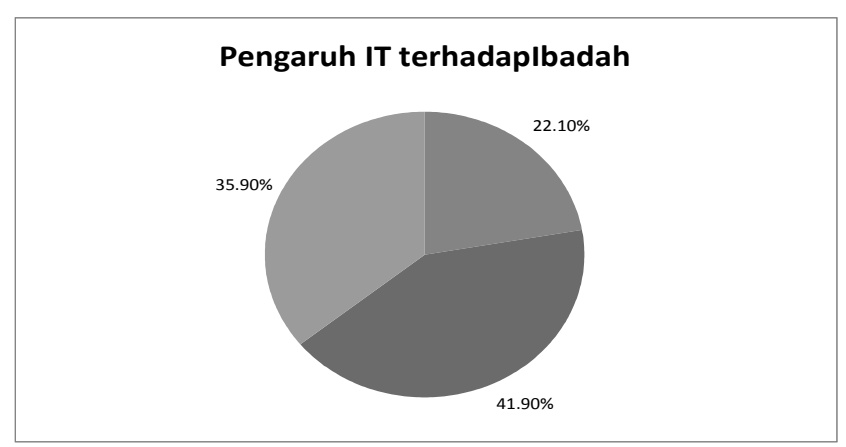

Gambar 20.

Pandangan mengenai Pengaruh IT terhadap Ibadah

Mengamati massifnya penggunaan gadget di kalangan mahasiswa, mahasiswa berpendapat bahwa penggunaan gadget memiliki pengaruh kuat terhadap ibadah: Meningkatkan Ibadah 48 responden (22,1\%), Menurunkan Ibadah 91 responden (41,9\%), Tidak Berpengaruh 78 responden (35,9\%). 
Data dalam Gambar 20 menunjukkan bahwa mayoritas mahasiswa (41,9\%) memandang bahwa IT berpengaruh dalam menurunkan ibadah. Pandangan yang lain menyatakan bahwa IT tidak berpengaruh terhadap ibadah $(35,9 \%)$ dan selebihnya $(22,1 \%)$ menyatakan bahwa IT meningkatkan ibadah.

\section{F. Kesimpulan}

Pendidikan agama di lingkungan Perguruan Tinggi Umum sangat diperlukan, tidak hanya sebatas melaksanakan peritah undang-undang, akan tetapi amanah yang harus dilaksanakan demi tercetaknya generasi unggulan baik sebagai teknokrat, birokrat, akademisi atau pengusaha yang pandai dari segi intelektual, namun shaleh secara spiritual. ITB dan Mesjid Salman terus bekerjasama dalam membangun karakter mahasiswa dengan berbagai macam kegiatan keagamaan. Meskipun usaha ini tidak mudah dan membutuhkan waktu yang tidak sebentar, akan tetapi peran pendidikan agama Islam di ITB memberikan dampak yang besar bagi para mahasiswa terutama dalam menghadapi Tantangan Global bidang sosial keagamaan akhir-akhir ini.

Dalam situasi di mana teknologi informasi menjadi sesuatu yang tidak terhindarkan dalam kehidupan, termasuk kehidupan mahasiswa, ternyata kebanyakan mahasiswa mengandalkan perolehan keilmuan keagamaannya dengan cara belajar dalam forum dunia nyata, meskipun ada juga yang memanfaatkan IT untuk belajar agama. Dengan demikian meski generasi muda merupakan kelompok sosial yang sangat dekat dengan IT namun mereka memiliki kekuatan untuk memilih media untuk belajar agama. Bahkan mereka juga meyakini bahwa IT mengganggu aktifitas keagamaan mereka.

Dalam pembentukan spiritualitas mahasiswa ITB, keberadaan Masjid Salman tidak boleh diabaikan. Peran masjid Salman sangat sentral dalam mengejawantahkan berbagai dakwah islamiyah mahasiswa ITB. Programprogram yang ditawarkan oleh Masjid Salman memiliki daya tarik tersendiri, baik bagi mahasiswa ITB sendiri maupun mahasiswa di luar ITB. Model diseminasi informasi, model pendidikan yang ditawarkan memberikan penanaman spiritualitas yang mendalam bagi peserta didik. Penggunaan IT daam proses pendidikan dan pelatihan di Masjid Salman merupakan jawaban bagi kebutuhan untuk mendekatkan generasi muda ke masjid.[w] 


\section{BIBLIOGRAFI}

Buku Data Pra Nikah Salman ITB 2015.

Fadhilatussaniah, Siti, "Metode Penyiaran Islam Yayasan Salman ITB dalam Menyajikan Informasi melalui Website: Studi Deskriptif tentang Website www.salmanitb.com” Tesis Diploma, Bandung: UIN Sunan Gunung Djati Bandung, 2011.

Farida, Anik "Islamisasi Sains dan Saintifikasi Islam: Model Manajemen Pemberdayaan di Masjid Salman ITB Bandung," Harmoni: Jurnal Multikultural dan Multireligius, Vol. 13, No. 1, 2014.

Fathurrazi, Asep, Strategi Peningkatan Mutu Pendidikan Islam, Tulungagung: Sekolah Tinggi Agama Islam Muhammadiyah Tulungagung, 2016.

Furqan, Pedagogi Spiritual, Bandung: Universitas Pendidikan Indonesia Bandung, 2016.

Hussin, Zaharah, " Mendidik Generasi Berakhlak Mulia: Fokus Peranan Guru Pendidikan Islam”, Masalah Pendidikan. Kuala Lumpur: Universiti Malaya, 2005.

http://kbbi.web.id/nikah. diakses 02 Novenber 2016. Pukul 20: 55.

https://id.wikipedia.org/wiki/Pubertas, diakses 02 November 2016. Pukul 21:07.

http://dosenit.com/kuliah-it/teknologi-informasi/dampak-positif-dan-negatifpenggunaan-teknologi-informasi-dan-komunikasi. diakses 02 November 2016. pukul: 21.11.

Masruri, Hadi dan Imron Rossidy, "Filsafat Sains dalam al-Qur'an: Melacak Kerangka Dasar Integrasi Ilmu dan Agama” dalam El-Qudwah Vol. 4, 2007

Mas'ud, Abdurrahman, Islamic Education, Democracy and Civil Society. Universitas Islam Negeri Walisongo Semarang, 2016.

Mukarromah, Khomsiatul, "Membangun Insan Kamil dari Perspektif Media: Media Literasi sebagai Kontrol sosial," Dirosat: Journal of Islamic Studies Vol. 1, No. 2, 2016.

Noor Azizah, Aulia Hening, Uswatun Hasanah, "Pengaruh Perkembangan IT Terhadap Intensitas Ibadah Mahasiswa S1 STEI ITB”, Laporan Penelitian, Bandung: ITB, 2016. 
Nurdin, Indra Fajar, Perbandingan Konsep Adab Menurut Ibn Hajar al-'Asqalany dengan Konsep Pendidikan Karakter di Indonesia, Yogyakarta: Universitas Islam Negeri Sunan Kalijaga Yogyakarta, 2015.

Nurudin, Perbandingan Pengelolaan Pendidikan Agama pada Sekolah di Indonesia dan Sekolah Republik Indonesia Tokyo. Pusat Penelitian dan Pengembangan Pendidikan Agama dan Keagamaan, Kementerian Agama Republik Indonesia, 2015.

Raharjo, Dawam, Insan Kamil: Konsepsi Manusia Menurut Islam, Jakarta: Pustaka Grafiti Pers, 1987.

Rubiyanti, Yanti, “Perilaku Generasi Z dengan Karakteristiknya serta Pengaruhnya terhadap Cara Belajar dari Sisi Psikologi dan Pendidikan", Simposium Nasional Pendidikan Tinggi, ITB, Bandung, Senin, 24 Oktober 2016, dalam laman http://event.elearning.itb.ac.id/assets/ download/ materi5.pdf

Student Outcome Mata Kuliah Umum, Institut Teknologi Bandung, 2016.

Surahman, Adang, "Pengalaman sebagai Dosen ITB Menghadapi Mahasiswa Generasi Z", Simposium Nasional Pendidikan Tinggi, ITB, Bandung, Senin, 24 Oktober 2016, tersedia dalam laman http://event.elearning.itb.ac.id/ assets/download/materi2.pdf

Suryadi, Rudi Ahmad, Visi dan Paradigma Pendidikan Agama Islam (PAI): Kualitas, Integratif, dan Kompetitif, Cianjur: STIS Nahdhatul 'Ulama Cianjur, 2016.

al-Syahrani, Fahd bin Mathar, Pendidikan Islam dalam Menghadapi Tantangan Global, Bandung: Universitas Pendidikan Indonesia Bandung, 2016.

Tafsir, Ahmad, Fisafat Pendidikan Islam, Bandung: Remaja Rosdakarya, 2012.

Wibawanto, Hari, "Generasi Z dan Pembelajaran di Pendidikan Tinggi," Simposium Nasional Pendidikan Tinggi, ITB, Bandung, Senin, 24 Oktober 2016, tersedia dalam laman http://event. elearning.itb.acid/assets/ download/materi3.pdf

Yoga S, Salam, "Dakwah di Internet: Konsep Ideal, Kondisi Objektif, dan Prospeknya," Jurnal Al-Bayan Vol. 21, No. 31, 2015.

Zuchdi, Darmiyati, "Pendekatan Pendidikan Nilai Secara Komprehensif sebagai Suatu Alternatif Pembentukan Akhlak Bangsa", Cakrawala Pendidikan: Jurnal Pendidikan, 2, 2001 
